UMGCINMATIC : $1^{\text {st }}$ Rethinking Education during Covid-19 Era: Challange and Innovation

\title{
PERCEPTION OF PARENTS' PARENTING PATTERNS IN CHOOSING A SPOUSE FOR WOMEN OF ARAB DESCENT
}

\author{
Author \\ Sabrina $^{1}$, Nadhirotul Laily ${ }^{2}$, Muhimmatul Hasanah ${ }^{3}$ \\ ${ }^{123}$ Psychology Study Program, Universitas Muhammadiyah Gresik \\ $\underline{\text { sabrinawakid@gmail.com }}^{1}$, nadhirotul.laily@umg.ac.id ${ }^{2}$, muhimmatul@umg.ac.id ${ }^{3}$.
}

ABSTRACT

Parent's upbringing is very important for the child's life to grow up, therefore parents should pay attention to the application of proper parenting so that later in adulthood the child can go to the next life, namely regarding partner selection. The purpose of this determination is to determine how the application of parenting styles in choosing partners for women of Arab descent, the factors that influence, and the impact that occurs due to parenting styles. This research using a qualitative approach with a case study method involving 4 subject with the consideration that this research is able to reveal, explore, and analyze various phenomena that occur. The results show that the four subjects get the application of democratic parenting from their parents. This is evidenced by the high dimensions of the control and the high dimensions of parental warmth. The factors that influence the parenting styles of the four subjects are from customs, culture, and religion. With the application of democratic parenting, children become happy, sociable, more controlled, and comfortable individuals. The application of democratic parenting can affect early adult women in terms of openness regarding potential partners, communication between parents and children, and decision making. The subject in this study were too few, only 4 people, so the data obtained were not too deep. For future researchers, it is better to add subject and find deeper data in order to get new findings.

Keyword: Parenting, Choosing a Partner, Women of Arab descent

\section{INTRODUCTION}

The development period is a process of change from one stage to the next. The development process must pass through the sequence of each stage from one to the next. One of the stages of individual development is early adulthood. Early adulthood is the core or point of a person's development, where at this stage many changes in an individual. Changes at this time of the physical, psychological, and cognitive. Not only that, the changes experienced are concurrent with matters of adjustment and demands that are [1]. In the early adulthood stage, a person is usually said to be of "productive age" where individuals are ready to face their tasks. 
One of the developmental tasks in early adulthood is choosing a life partner or choosing a partner. The early adult stage enters the Intimacy vs Isolation stage. Intimacy (familiarity) means that the identity of an individual can be united with the identity of others. The ability to share mutual trust, unite commitment, compromise and sacrifice in an equal relationship. On the other hand, if the explanation of the meaning of isolation means not being able to work together and make more serious relationships with other people. That way, according to the explanations of some experts, an individual in this early adult stage will choose a life partner.

Choosing a life partner is not an easy thing, every individual must think carefully. Choosing a life partner deserves special attention because this stage is only done once in a lifetime and is expected to be the best choice. The process of selecting a life partner must be done correctly so that married life will run well and according to what is expected. Every country, region and culture has a different way of choosing a partner. In choosing a partner, culture greatly influences an early adult woman in choosing a partner, because she has to think about the environment[3]. Researchers conducted an initial survey on December 11, 2019 in Gapuro Sukolilo Village. The results show that the population of early adult female population aged 18-40 years [1], there are 1234 people. The data were regrouped with the results of 147 not marriedyet early adult women (data from location). In addition, researchers conducted initial interviews with five respondents. The interviews were conducted on different days for each subject. I 21 years a woman of Arab descent still single.

"If the problem of marriage is a tradition in Arab descent, it's like seeing it at home. For example, if someone is interested in a girl, the boy will visit the girl's house. The guy is not alone, sometimes with his father or mother. If the two match, then do engagemen."(I, 21 years)

Based on the statement from I, revealed that the tradition in Arab descent when choosing a partner is to first visit the house of the woman they want, then when they meet the two, they immediately get to know each other more deeply and determine the time when a man can propose to a woman. The process carried out is called ta'aruf (approach according to Islam). In addition to the ta'aruf process, parents usually take a bigger role when the child chooses a

partner. Parents are always supervising, and the biggest decision maker if the child submits an opinion. Parents of Arab descent have their own criteria that are different from the child. This creates controversy because what happens is usually not in accordance with the wishes of the 
parents. In the family, it is rare for children to ask for something or talk about something to father (father). Most, delivered first through the ummi (mother). The fear factor appears first, making it difficult for children to open up, let alone express various objections [4].

[5] In the selection of partners, the case of the first subject, the factors that influence both externally and internally are related to the parents' decisions. Parents can influence their children because parents have power. The power that parents have can be due to the influence of information. Information conveyed by parents in choosing a life partner can be perceived if the information (stimulus) is strong enough so that the child can understand it [6]. [7] so that the stimulus can be perceived, the stimulus should be strong enough, past the stimulus threshold, the stimulus strength is minimal but can produce awareness, and can be perceived by the individual. Another requirement so that the stimulus can be perceived regarding information from parents is the relationship between parents and children and how parents provide this information. In this case, parents have the main role and full control. [8] argues that Saudi Arabia's parenting style is controlling, so it is far from democratic. Researchers conducted initial interviews with five respondents related to the parenting style applied by their parents. The five respondents perceived that they received an authoritarian upbringing, their parents considered the subject still to be supervised.

Parenting in principle is parental control. Parenting is parental control over children. The characteristics above are almost the same as the characteristics of authoritarian parenting. In authoritarian parenting, all the will is in the hands of parents and parents are the number one control over their children's lives. Parents who apply this parenting style may have principles about past experiences that were applied by their parents in raising children. Children are required to obey all the rules made by parents. If the child violates, the parents will punish the child.[10] Parenting is a very important thing, because it has an impact on early adult women to continue their stage of life and mindset. Parents as a shaper of the personality of early adult women from an early age. The parenting style applied is able to encourage early adult women

to achieve life goals, one of which is during the process of choosing a partner. Parenting is the initial foundation of a child to face his life. Authoritarian parenting is carried out by parents who try to build, control, evaluate the behavior and actions of children to comply with standard rules. These standard rules are usually fixed, motivated by a doctrinal spirit and enforced with great influence. Child compliance is a priority value, by imposing penalties when violations occur.

\section{THEORETICAL FRAMEWORK}

\section{a. Choose a life partner}

[11] The preference for choosing a life partner is to choose someone who is desired to 
be able to become a life partner, an individual who is able to become a partner to become parents of their children later. [12] The selection of individual partners is based on the similarity of several characteristics or traits that exist in the individual. Choosing a life partner is choosing a candidate who can complete what is needed from the individual and based on a thought that an individual will choose a life partner who can complete the required needs. The following is the process of selecting a life partner.[13]

Tabel 1. Life partner selection process

\begin{tabular}{l}
\hline Field of Eligibles \\
\hline Propinquity Filter \\
\hline Attraction Filter \\
Physical Attraction Personality \\
\hline Homogamy Filter \\
Age, education, social class, religion \\
\hline Compability Filter \\
Temperament, attitudes and values, needs, roles and habit systems \\
Trial Filter Cohabition \\
Engagement \\
\hline Decision Filter \\
Married
\end{tabular}

\section{b. Perceptions of parenting}

Perception is the ability to select, classify, and focus attention on a stimulus object (impulse). In the process of grouping this perception includes a process of interpretation or reexplanation based on experience of an event or target [14]. [15] Perception is the process of combining the sensations received by the organs and the results of their interpretation. There is additional information which is a form of interpretation (involving the meaning obtained). Perception is the experience of objects, events, or relationships obtained by drawing conclusions from the information and interpreting the messages obtained.[16]

9] Parenting in principle is parental control. Parenting is parental control over children. Parents play a role in the supervision, examination, and control of children. Parental supervision is needed so that children act in accordance with applicable values and norms. Parenting is a combination of behaviors, practices and non-verbal expressions of parents which are purely characterized by the interaction of parents with children throughout the 
developing conditions [17]. [18] Parenting is a parenting method used by parents so that children can grow and develop to form socially mature individuals. Based on the definitions from several experts, it can be concluded that the perception of parenting is the child's assessment of the attitude of parents who make rules and pour love into their children.

The dimensions of parenting can be seen in the image below:

$$
\begin{array}{ll}
\text { Authoritarian } & : \uparrow \text { Demandingness/Control } \downarrow \text { Acceptance/Responsiveness } \\
\text { Authoritative } & : \uparrow \text { Demandingness/Control } \uparrow \text { Acceptance/Responsiveness } \\
\text { Permissive } & : \downarrow \text { Demandingness/Control } \uparrow \text { Acceptance/Responsiveness } \\
\text { Uninvolved } & : \downarrow \text { Demandingness/Control } \downarrow \text { Acceptance/Responsiveness }
\end{array}
$$

Picture 1. Parenting Dimensions [19]

Table 2 Correlation of Parenting Patterns with Children's Behavior[18]:

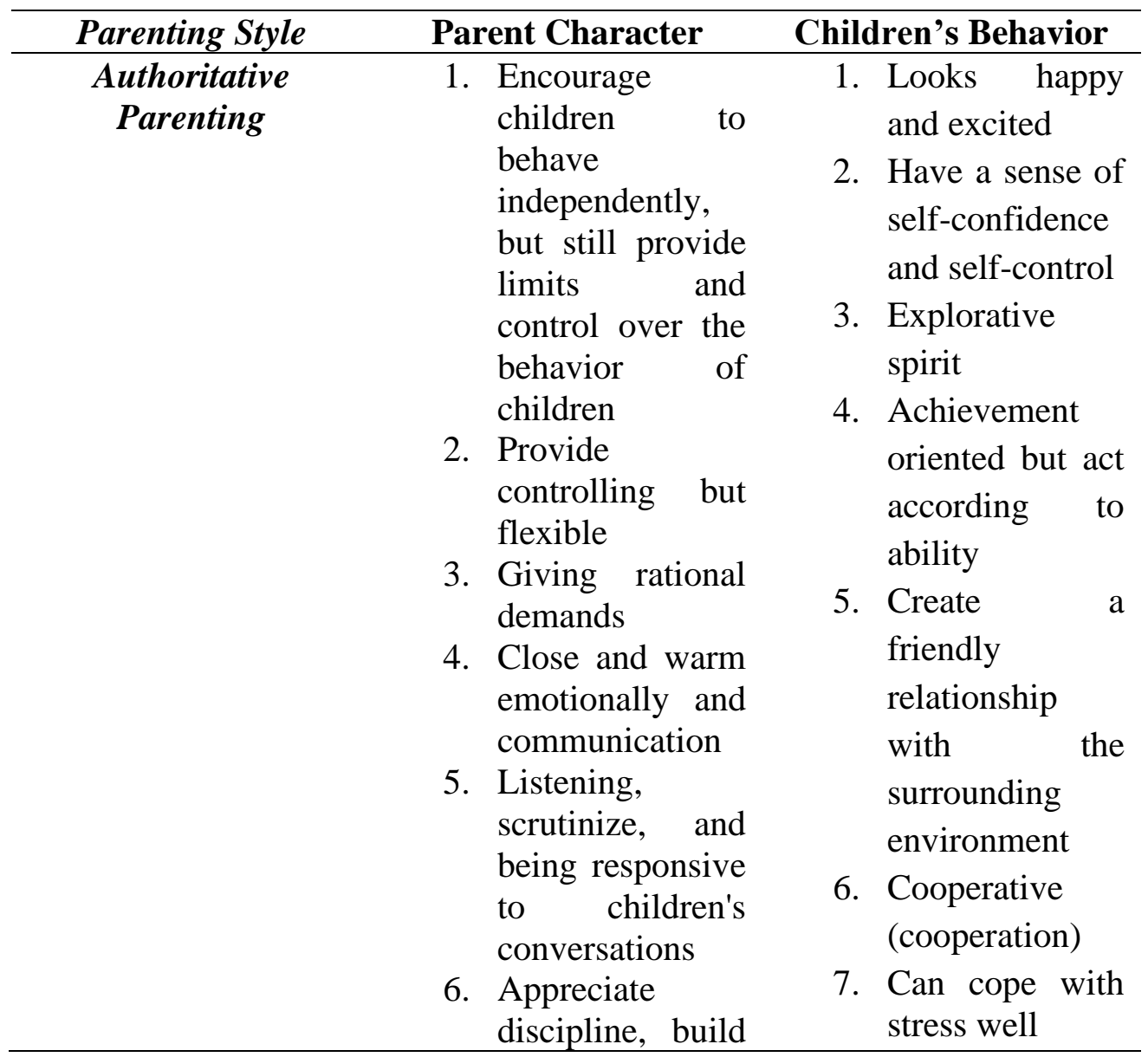




\begin{tabular}{|c|c|c|}
\hline & $\begin{array}{l}\text { children's } \\
\text { confidence } \\
\text { 7. Show a happy } \\
\text { response and } \\
\text { support for the } \\
\text { behavior of the } \\
\text { child }\end{array}$ & \\
\hline $\begin{array}{c}\text { Authoritarian } \\
\text { parenting/adult } \\
\text { centered }\end{array}$ & $\begin{array}{l}\text { 1. Implement strict } \\
\text { self-control } \\
\text { 2. Evaluate } \\
\text { children's } \\
\text { behavior and } \\
\text { attitudes with } \\
\text { absolute } \\
\text { standards } \\
\text { 3. Value obedience, } \\
\text { respect adults } \\
\text { and traditions }\end{array}$ & $\begin{array}{l}\text { 1. Acting not as } \\
\text { desired } \\
\text { 2. Seems aimless } \\
\text { 3. Less happy, } \\
\text { withdrawing } \\
\text { from society, } \\
\text { fear and lack of } \\
\text { confidence } \\
\text { when with other } \\
\text { people }\end{array}$ \\
\hline $\begin{array}{c}\text { Indulgent Parenting } \\
\text { /Permissive (Child } \\
\text { Centered) }\end{array}$ & $\begin{array}{l}\text { 1. } \begin{array}{l}\text { Involved } \\
\text { children's } \\
\text { activities, but } \\
\text { lack } \\
\text { controlling and } \\
\text { demanding } \\
\text { attitude } \\
\text { 2. Freedom to do } \\
\text { something the } \\
\text { child wants } \\
\text { 3. } \\
\text { Discussed with } \\
\text { children about all } \\
\text { policies }\end{array}\end{array}$ & $\begin{array}{l}\text { 1. } \begin{array}{l}\text { Not even } \\
\text { controlling the } \\
\text { child's behavior }\end{array} \\
\text { 2. Lack of } \\
\text { confidence } \\
\text { 3. Appears } \\
\text { impulsive and } \\
\text { aggressive } \\
\text { behavior and } \\
\text { always acts as } \\
\text { he pleases } \\
\text { 4. Do more free } \\
\text { exploration } \\
\text { 5. 5. Have low } \\
\text { self-control }\end{array}$ \\
\hline $\begin{array}{c}\text { Neglectful } \\
\text { Parenting/Uninvolved }\end{array}$ & $\begin{array}{l}\text { 1. Parents who are } \\
\text { not involved in } \\
\text { children's } \\
\text { activities } \\
\text { 2. No demands and } \\
\text { control } \\
\text { 3. Not interested in } \\
\text { children's } \\
\text { opinions, views } \\
\text { and activities }\end{array}$ &  \\
\hline
\end{tabular}




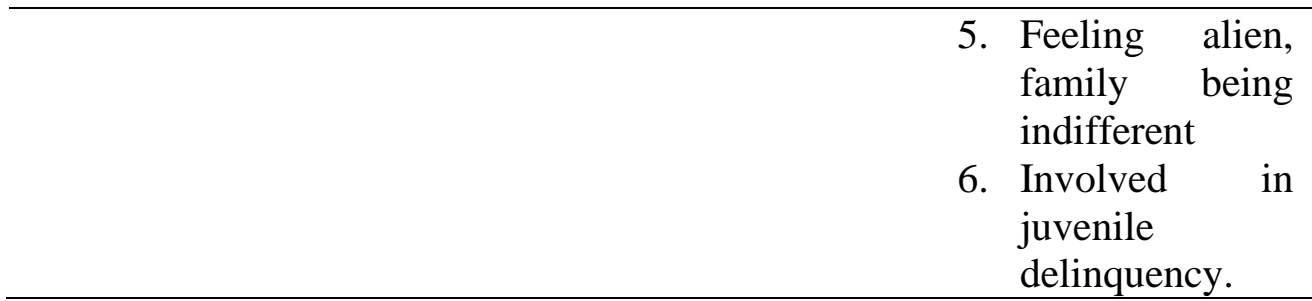

\section{METHODS}

The research used is qualitative research. Qualitative research is research that produces descriptive data including written or spoken words from people obtained from interview data and behavior that can be observed or observed [20]. The type of research used in this qualitative research is a case study. A case study is a special phenomenon that is present in a bounded context. The case can be an individual, a role, a small group, an organization, a community, or even a nation. Cases can also be in the form of decisions, policies, processes, or certain special events [21]. In this study, the researcher used a snowball sampling technique. Snow ball sampling is a technique of sampling data sources, initially only a few, then over time it becomes large. This was done because of the small number of data sources, they still did not get in-depth data, therefore researchers were looking for other people who could be used as data sources [22]. This study uses four subjects, which have the following characteristics: (1) Early adult women aged 18-40 years, (2) x village residents (3) not married yet (4) plans for marriage

The subjects in this study are:

$\begin{array}{llll}\text { HG } & \text { : Subject 1 } & \text { AB } & \text { : Subject } 3 \\ \text { ER } & \text { : Subject 2 } & \text { JB } & \text { : Subject } 4\end{array}$

Data collection techniques used are interviews and observation. [23] Interview is a process to obtain the desired information and data from the research objectives by conducting a face-to-face question and answer session between the respondent and the researcher, using or without an interview guide. Therefore, there are several types of interviews to assist in the process pengumpulan data. Observation is the foundation of all knowledge. Scientists can only work based on the data obtained, namely facts or truths that exist in the field related to the world of reality obtained through the observation process.[22]

The data analysis technique used is qualitative data analysis technique. Qualitative data analysis is an effort that is used according to what is obtained from the data, grouping the data, 
sorting out data that can be processed, synthesizing, looking for and finding patterns, getting what is important and what needs to be learned from the data, determining which ones can be used. told to other individuals.[20]

\section{RESULT AND DISCUSSION}

Researchers conducted interviews with the four subjects, overall the parenting style applied by their parents was democratic parenting, this was evidenced by the answers during the interview, namely the high warmth and demands that parents gave to their children. [24] The application of democratic parenting is also characterized by parents having a warm attitude towards their children but parents asking for maturity demands for their children, controlling children's attitudes, and establishing good communication between parents and children.

On the subject of $\mathrm{HG}$, Based on the explanation of $\mathrm{HG}$, parents applied a high level of control and a high attitude of warmth to HG. Based on the discussion above, HG's parents apply democratic parenting because of the attitude of monitoring the subject's activities, monitoring the selection of prospective partners and the responsive attitude between parents and subjects [9]. In the ER subject, as with the HG subject, the application of parenting by parents is democratic parenting. However, in choosing a partner, ER's parents require that ER get a potential partner of Arab descent. It aims to continue and continue the lineage or lineage. More inclined to choose a partner who has a lot in common is called homogamy. Similarity in Characteristics such as age, race, ethnicity, education level, social and religion.[13]

In the subject of $\mathrm{AB}, \mathrm{AB}$ 's parents apply democratic parenting because of the attitude of monitoring the subject's activities, monitoring the selection of prospective partners and the responsive attitude between parents and subjects [9]. In addition, regarding the selection of a potential partner, the decision to choose a partner is in the hands of the parents before the subject is determined. [5] In the matter of choosing a partner, the first subject matter, the factors that influence outside and inside is related to the decision of the subject's parents. On the subject of JB, at the time of determining the decision to choose a partner, JB's parents who determined then returned to JB what the final decision according to JB was. JB's parents want JB to get a potential partner who is responsible, well behaved, and from a good family. Based on the Stimulus-ValueRole Theory, the first attention to individuals regarding attraction to a potential partner comes from physical appearance, social status, quality, way of dressing, and others. Parents and JB also find out about the personality of the prospective partner, the association in their environment, and their 
habits[25]. When the individual is at the stage of choosing a life partner, the thing to do is carry out a selection and screening process to determine certain desired criteria (filter theory).[26]

This summary of research results that have been carried out by researchers:

Table 3. Summary of Research Results

\begin{tabular}{|c|c|c|c|c|c|}
\hline No & Topic & Subject HG & Subject ER & Subject AB & Subject JB \\
\hline 1 & $\begin{array}{c}\text { Democratic } \\
\text { parenting }\end{array}$ & $\begin{array}{l}\text { here is an attitude } \\
\text { of monitoring } \\
\text { the subject's } \\
\text { activities, } \\
\text { monitoring in } \\
\text { terms of } \\
\text { choosing a } \\
\text { potential partner } \\
\text { and a responsive } \\
\text { attitude between } \\
\text { parents and the } \\
\text { subject, having } \\
\text { self-disclosure, } \\
\text { and contributing } \\
\text { to each other in } \\
\text { terms of } \\
\text { preparing for a } \\
\text { potential partner. }\end{array}$ & $\begin{array}{l}\text { lere is an attitude } \\
\text { of monitoring the } \\
\text { subject's } \\
\text { activities, } \\
\text { monitoring the } \\
\text { selection of } \\
\text { potential partners } \\
\text { and a responsive } \\
\text { attitude between } \\
\text { parents and } \\
\text { subjects, } \\
\text { establishing } \\
\text { good } \\
\text { communication } \\
\text { between children } \\
\text { and parents, and } \\
\text { having time } \\
\text { together. }\end{array}$ & $\begin{array}{l}\text { here is an } \\
\text { attitude of } \\
\text { monitoring the } \\
\text { subject's } \\
\text { activities, } \\
\text { monitoring in } \\
\text { terms of } \\
\text { choosing a } \\
\text { potential } \\
\text { partner and a } \\
\text { responsive } \\
\text { attitude } \\
\text { between } \\
\text { parents and } \\
\text { subjects, } \\
\text { preparing for } \\
\text { joint } \\
\text { application } \\
\text { events, } \\
\text { supporting } \\
\text { activities, and } \\
\text { being open to } \\
\text { each other. }\end{array}$ & $\begin{array}{l}\text { lere is an } \\
\text { attitude of } \\
\text { monitoring the } \\
\text { subject's } \\
\text { activities, } \\
\text { monitoring in } \\
\text { terms } \\
\text { choosing a } \\
\text { potential } \\
\text { partner and a } \\
\text { responsive } \\
\text { attitude } \\
\text { between } \\
\text { parents and the } \\
\text { subject and } \\
\text { parents } \\
\text { providing } \\
\text { support in all } \\
\text { things and } \\
\text { directing the } \\
\text { subject. }\end{array}$ \\
\hline 2 & $\begin{array}{r}\text { Factors } \\
\text { affect pa }\end{array}$ & $\begin{array}{l}\text { Factors that } \\
\text { influence } \\
\text { parenting } \\
\text { patterns of HG } \\
\text { subjects are } \\
\text { previous } \\
\text { experiences in } \\
\text { raising children, } \\
\text { namely parents } \\
\text { applying the care } \\
\text { from generation } \\
\text { to generation } \\
\text { (custom). }\end{array}$ & $\begin{array}{l}\text { Factors that } \\
\text { influence } \\
\text { parenting ER } \\
\text { parents are based } \\
\text { on religion. }\end{array}$ & $\begin{array}{l}\text { Factors that } \\
\text { influence the } \\
\text { parenting style } \\
\text { of AB's } \\
\text { parents come } \\
\text { from the } \\
\text { customs and } \\
\text { culture that } \\
\text { teach them. }\end{array}$ & $\begin{array}{l}\text { Factors that } \\
\text { influence the } \\
\text { parenting style } \\
\text { of JB's parents } \\
\text { are based on } \\
\text { religion. }\end{array}$ \\
\hline 3 & $\begin{array}{l}\text { The impact of } \\
\text { parenting }\end{array}$ & $\begin{array}{l}\text { The impact of } \\
\text { the subject's } \\
\text { parental care is }\end{array}$ & $\begin{array}{l}\text { The impact of the } \\
\text { subject's parental } \\
\text { care is that he }\end{array}$ & $\begin{array}{l}\text { The impact of } \\
\text { the subject's } \\
\text { parental care is }\end{array}$ & $\begin{array}{l}\text { The impact of } \\
\text { parental care is } \\
\text { that he }\end{array}$ \\
\hline
\end{tabular}




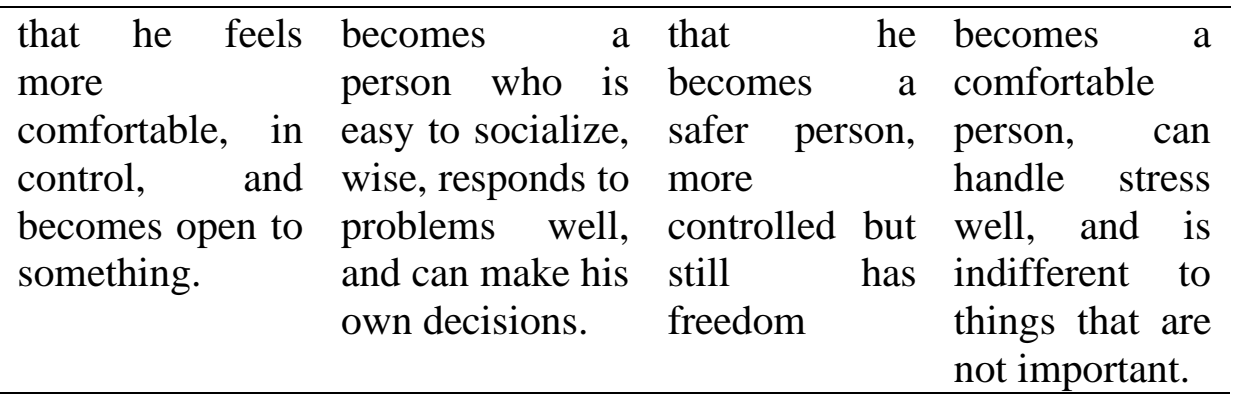

\section{CONCLUSION}

Based on the information obtained from the results of research on the subjects $\mathrm{HG}, \mathrm{ER}, \mathrm{AB}$, and JB which includes the dimensions of parenting, factors, and the impact of parenting, it can be concluded that the perception of parenting patterns in choosing a partner in women of Arab descent is almost all parents from the four subjects apply democratic parenting. Where parents pay attention to preparation for the selection of a potential partner, warmth in communication about potential partners, and having time together with children. Parents also contribute to the preparation and needs of children with potential partners. Parents are also firm in terms of prohibitions, boundaries, and discipline with potential partners. Parents want their children to be socially responsible, self-regulated and cooperative. Parents also provide direction in domestic life.

The factors that influence parenting patterns on the subject of $\mathrm{HG}$, the influencing factor is previous experience in raising children, namely parents apply parenting from generation to generation from grandmother. In the subject of ER, the factors that influence parenting are based on religion. Same as subject JB. While the subject AB said that the factors that influence the parenting applied are the culture and customs adopted by the family. Of the four subjects, the impact obtained from their parents was very different. In the HG subject, the behavior that appears is that she becomes a comfortable person, more controlled and open to something. subject ER, she is a wise person, easy to socialize, responds to problems well, and is able to make her own decisions. In the subject of $\mathrm{AB}$ she became a more secure and controlled person but still free. On the subject of JB, she feels happier, can handle stress well, and is indifferent to things that are not important.

\section{REFERENCES}

Hurlock, E. (2009). Psikologi Perkembangan. Jakarta: Erlangga

Alwisol. (2009). Psikologi Kepribadian. Malang: UMM Press.

Hoesni, S. M. (2019). Gambaran Preferensi Pemilihan Pasangan Hidup Pada Mahasiswa Universitas Kebangsaan Malaysia. An - Nafs: Jurnal Fakultas Psikologi , 13 (2), 96107.

Chalifa, G. (2008). Abah Seolah Penguasa Ummi Yang Berkuasa (Esai-esai Pergeseran 
Budaya Arab). Jakarta: Khatulistiwa Press.

Fatimah, M. (2013). Pengambilan Keputusan Memilih Pasangan Untuk Menikah Pada

Perempuan Keturunan Arab. Thesis, Universitas Pendidikan Indonesia, Fakultas Ilmu

Pendidikan Program Studi Psikologi, Bandung.

Saraswati, P. (2011). Hubungan Antara Persepsi Anak Terhadap Peran Orang Tua Dalam

Pemilihan Pasangan Hidup Dengan Kecenderungan Pemilihan Pasangan Hidup

Berdasarkan Status Sosial Ekonomi Pada Dewasa Awal. Jurnal Psikologi , 6 (1), 347364.

Walgito, B. (1994). Psikologi Sosial (Suatu Pengantar). Yogyakarta : Andi Offset.

Dwairy, d. (2006). Parenting Style in Arab Society. Journal Of Cross-Cultural Psychology,

37 (3), 1-18

Baumrind, D. (1991). Current Pattern of Parental Authority. Developmental Psychology Monograph , 4 (1), 56-95.

Agency, A. (2014). Mengembangkan Pola Asuh Demokratis. Jakarta: PTElex Media Komputindo.

Tellegen, L. (1993). Is Human Mating Adventitious or The Result of Lawful Choice? A Twin Study of Mate Selection. Journal of Personality and Social Psychology , 65 (1), 56-68.

Buss, D. M. (1986). Preference in Human Mate Selection. Journal of Personality and Social Psychology , 50 (3), 559-570.

DeGenova, M. K. (2008). Intimate Relationship, Marriages, and Families (7th ed.). New York: McGraw-Hill.

Shaleh, A. R. (2004). Psikologi Suatu Pengantar Dalam Perspektif Islam. Jakarta: Kencana. Sarwono, S. W. (2018). Pengantar Psikologi Umum. Depok: Rajawali Pers.

Jalaludin, R. (2005). Psikologi Komunikasi . Bandung : Rosdakarya.

Steinberg, D. (1993). Parenting Style As Context: An Integrative Model. Psychological Bulletin , 113 (3), 487-496.

Santrock, J. W. (2012). Life-Span Development Perkembangan Masa Hidup (Edisi Ketigabelas jilid 1). Jakarta: Erlangga.

Maccoby E. E, M. J. (1983). Socialization In The Context Of The Family: Parent-Child Interaction. (E. M. Mussen, Ed.) Handbook of Child Psychology, 4 (Socialization Personality, And Social Development), 1-110.

Moleong, L. J. (2016). Metode Penelitian Kualitatif. Bandung: Remaja Rosdakarya.

Poerwandari, E. K. (2013). Pendekatan Kualitatif Untuk Penelitian Perilaku Manusia. Depok: LPSP3 UI

Sugiyono. (2017). Metode Penelitian Manajemen. Bandung: Alfabeta.

Burhan, B. (2011). Penelitian Kualitatif. Jakarta : Kencana Predana Media Group

Ribeiro, L. L. (2009). Construction and Validation of A Four Parenting Style Scale. Thesis, Humboldt State University California, Faculty of Psychology.

Olson, D. (2003). Marriage and Families (8th ed.). New York: Mc Graw Hill. 
UMGCINMATIC : $1^{\text {st }}$ Rethinking Education during Covid-19 Era: Challange and Innovation Volume 1 No 2

Kerckhoff, C. D. (1962). Value Consensus and Need Complementary In Mate Selection. American Sosiological Review , 27, 295-303. 